\title{
Plant density influence on life history traits of a perennial herb in rocky outcrops, southeastern Brazil
}

\author{
Guilherme Ramos Demetrio',* (D), Mario Eduardo Avelar Barbosa² (D), Flávia de Freitas Coelho² \\ ' Universidade Federal de Alagoas, Laboratório de Ecologia Vegetal, Campus Arapiraca, Unidade Educacional Penedo, \\ Avenida Beira-Rio, s/n, 57200-000, Penedo, Alagoas, Brasil. \\ ${ }^{2}$ Universidade Federal de Lavras, Laboratório de Ecologia Evolutiva de Plantas Herbáceas, Departamento de Biologia, \\ Setor de Botânica, Campus Universitário, s/n, 37200-000, Lavras, Minas Gerais, Brasil. \\ *Autor para correspondência gramosdemetrio@gmail.com
}

Recebido em 17.V.2016

Aceito em 25.VI.2020

DOI 10.21826/2446-82312020v75e2020014

\begin{abstract}
Rocky outcrops support a great diversity of edaphic conditions and associated vegetation mosaics greatly determined by factors like local topography and micro-environment. The vegetation is grouped, and clonal plants may form patches with different densities. Densitydependent responses are an important component of organism's life-histories. We evaluated the density effects on Vellozia albiflora traits. We settled 20 monospecific patches of $V$. albiflora with different densities and sampled vegetative and reproductive traits. We compared traits between plants experimenting densely crowded and uncrowded conditions. $V$. albiflora rosettes present larger sizes and higher production of sexual reproductive structures in high densities. We concluded that $V$. albiflora probably allocates more resources to sexual reproduction in response to high-density conditions, which may allow a higher survival of offspring, since seeds are able to endure in soil and germinate under better density conditions, whereas the propagules generated by asexual reproduction must establish right after their production.
\end{abstract}

Keywords: clonal plant, inselbergs, persistence strategies, Vellozia albiflora

RESUMO - Influência da densidade de plantas em traços de história de vida de uma herbácea perene em afloramentos rochosos, no sudeste brasileiro. Afloramentos rochosos apresentam grande variedade de condições edáficas e mosaicos vegetacionais, determinados por fatores como topografia local e microambientes. A vegetação ocorre agrupada, e plantas clonais formam manchas com diferentes densidades. Respostas dependentes de densidade são importantes nas histórias de vida dos organismos. Avaliamos efeitos da densidade em traços de Vellozia albiflora Pohl. Marcamos 20 manchas de $V$. albiflora com diferentes densidades e amostramos altura, diâmetro, número de folhas, flores e escapos e comprimento dos escapos para todas as rosetas em cada mancha. Comparamos os traços amostrados entre as condições de densidade. Rosetas de $V$. albiflora foram maiores, com maior quantidade de estruturas reprodutivas sexuadas em altas densidades. $V$. albiflora provavelmente aloca mais recursos para a reprodução sexuada em resposta à alta densidade, que pode proporcionar maiores chances de sobrevivência da prole, porque sementes podem aguardar por melhores condições de germinação, como densidades menores, ao contrário da prole da reprodução assexuada.

Palavras-chave: estratégias de persistência, inselbergs, planta clonal, Vellozia albiflora

\section{INTRODUCTION}

The vegetation of rocky outcrops is grouped in islands formed by one or more species fixed directly on the rocks or in shallow soils (Conceição \& Giulietti 2002, Porembski 2007). These vegetation mosaics are determined by factors like local topography and micro-environmental characteristics (Benites et al. 2007). Rocky outcrops support very specialized vegetation and are associated to stressing habitats (Scarano et al. 2001) where monocotyledonous mats are often found as patches surrounded by bare rock (Medina et al. 2006, Porembski 2007). Plant species in these mats are frequently found at different densities. Some plant groups show clear specialization for survival in these environments, such as in the case of the resurrection plants in South America, mainly Cyperaceae and Velloziaceae (Meireles et al. 1997).

Many studies deal with density effects on plants life history traits, and they show very different plastic responses depending on the life history trait analyzed. Regarding morphology, leaves size, for example, were greater in high-density conditions than in low-density conditions for Pistia stratiotes L., Eichhornia crassipes (Mart.) Sölms., Sagittaria montevidensis Cham. \& Schltdl. (Coelho et al. 2005, Alvarenga et al. 2013, Demetrio et al. 2014a). In relation to plants reproductive modes, clonal plants would allocate more energy to sexual reproduction, which should increase at the expense of clonal growth, with increases in density. At low densities, increased allocation to clonal growth would facilitate rapid spread with low risk. On the 
other hand, at higher densities local conditions for growth would be unfavorable because of crowding (Abrahamson 1975). These results were corroborated by Coelho et al. (2005) and Komac \& Alados (2012). High density can also generate different effects on plant population size, since there will be a bias in the reproductive mode used by the individuals submitted to different density conditions (Plaza et al. 2012).

Various studies focusing on plant ecology in Brazilian tropical rocky outcrops have been done (Porembski et al. 1998, Ribeiro \& Fernandes 2000, Scarano et al. 2001, Medina et al. 2006, Coelho et al. 2014, Demetrio et al. 2014b), and despite one of them showed the relationship between Vellozia height and flowers number to herbivores abundance (Landau et al. 1998), none of them addressed plants life history traits and relations with density. Our study aimed to evaluate the density-dependent responses of life history traits of a perennial herb, Vellozia albiflora Pohl (Velloziaceae), by testing the following hypotheses: (i) The number of reproductive structures (flowers and flower scapes) will be higher in high plant densities, and (ii) The flower scapes length will be lower in high plant densities and, (iii) The height and diameter of the plants will be lower in high plant densities.

\section{MATERIALS AND METHODS}

\section{Study area}

We carried out the study at gneiss outcrops of Morro do Cruzeiro (4322'10’W; 1953'23”'S), in São Gonçalo do Rio Abaixo, a city located in Minas Gerais, Brazil (Fig. 1). The study area is part of the Estação de Pesquisa e Desenvolvimento Ambiental de Peti (EPDA-Peti), a particular area belonging to the Energetic Company of Minas Gerais (CEMIG). The area presents a rugged relief formed by counterforts of the Espinhaço Mountain Range. The local vegetation is mainly composed by riparian forests, seasonal semideciduous forests and herbaceous vegetation covering gneiss rocky outcrops (Pedralli \& Teixeira 1997, Borba \& Braga 2003).

\section{Terminology}

Clonal plants may present offspring production by sexual and asexual ways. Harper (1977) defined the produced individuals as genets and ramets, respectively. However, these two distinct categories of individuals can be related to different structures depending on the studied taxa. A genet is an individual formed through sexual reproduction by seed formation. The ramet, on the other hand, is defined as an individual formed by vegetative growth and is physiologically independent of its parental plant.

In the case of our study, we only sampled populations with ramets forming clones. In Vellozia albiflora these ramets are morphologically characterized by their habit of growing in a rosette from which scapes with flowers appear. In this species, the seedling originating from seed besides being a genet is also a ramet. A group of ramets produced vegetatively and connected by rhizomes also form a genet. Therefore, in this species, a genet can contain one (individual ramet) or several ramets (colonies of connected ramets) linked by rhizomes. We considered the rosette (shoot forming) and its associated root system as a ramet. Hereafter we call all the ramets as rosettes.

\section{Study species}

Velloziaceae is a botanical family, which occurs mainly in rupestrian grasslands and rocky outcrops. The plants belonging to this family are perennial organisms that usually

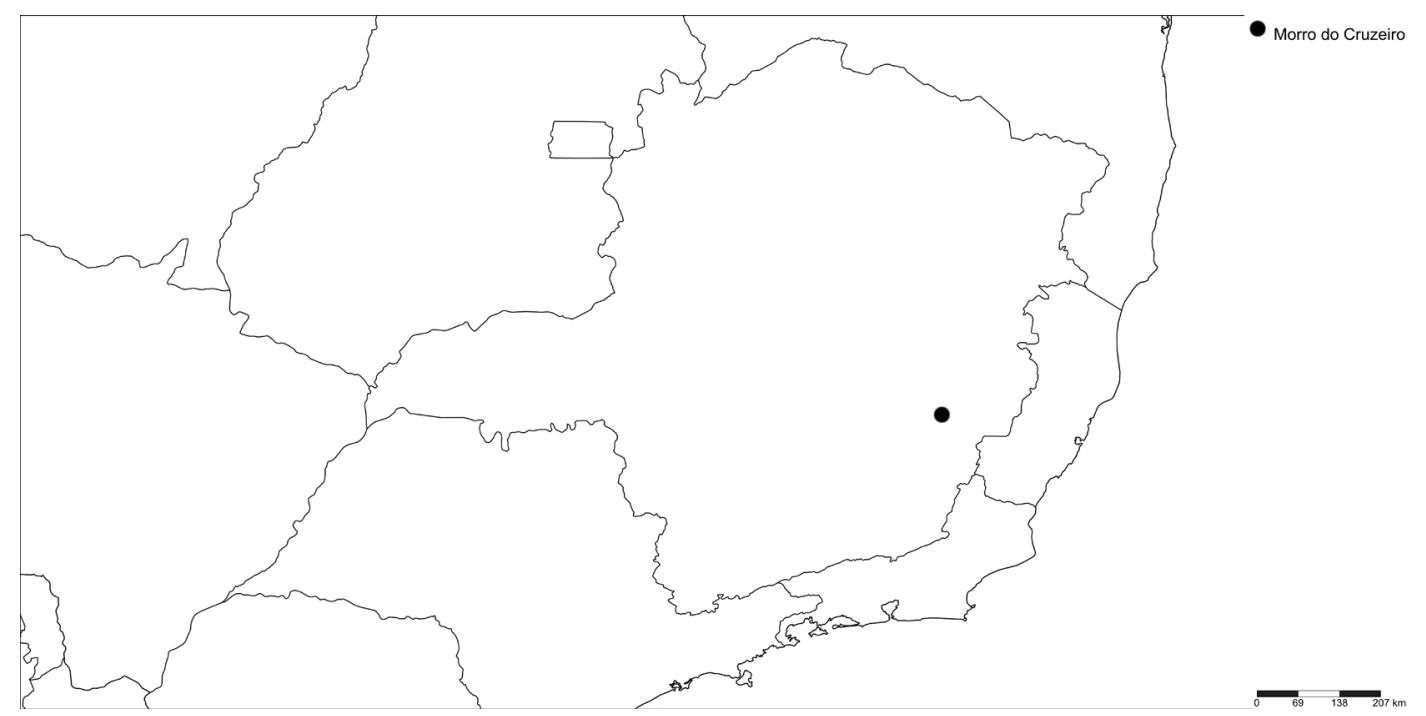

Fig. 1. Map of the studied area, showing the location of Estação de Pesquisa e Desenvolvimento Ambiental de Peti on Minas Gerais State, Brazil. 
inhabit shallow and poor soils with higher organic matter content and a low proportion of small particles (Rapini et al. 2008). The family is very representative in the rocky outcrops vegetation of the Espinhaço Range, southeastern Brazil (Giulietti \& Pirani 1988), a region with very high level of endemism, probably associated with the altitudinal isolation (Alves \& Kolbek 1994).

Vellozia albiflora (Fig. 2a), popularly known as "canelade-ema", is an herbaceous plant well distributed along the Espinhaço Range, the Órgãos Range and the Mantiqueira Range (Mello-Silva 2009). It usually occurs in rocky outcrops and rupestrian grasslands. In our study, clonal specimens of $V$. albiflora were found forming vegetation islands in gneiss rocky outcrops.

\section{Plant sampling}

We performed one sampling event in October 2010, when 20 monospecific vegetation mats (patches) formed by $V$. albiflora rosettes were sampled. Some specimens were in full blooming, while others showed only flower scapes. We selected 10 mats with low density of rosettes and another 10 with high density of rosettes, and sampled the rosettes by using a sampling quadrat of $2 \mathrm{~m}^{2}$. Density of $V$. albiflora was recorded by estimating the percentage of the quadrat covered by vegetation: $<30 \%$ of the quadrat characterizes low-density conditions, and $>60 \%$ of the quadrat covered by vegetation characterizes high-density (Coelho et al. 2005; Alvarenga et al. 2013) (Fig. 2b). Inside each quadrat we took the following measures for all rosettes of V.Albiflora: 1) vegetative height; 2) diameter; 3 ) number of leaves; 4) number of reproductive structures (flowers and scapes - in this sense, some plants presented scapes, but not flowers, indicating that the sexual reproduction occurred in a recent past); 5) maximum length of the flower scape.

\section{Data analysis}

All variables of morphological traits were tested for normality with Shapiro-Wilk tests. To evaluate the influence of plant density on V. albiflora life history traits, we applied GLMM's with Gaussian distribution for all life history traits that were measured. In order to account for local differences among plant mats, for every model, the mat was inserted as a random factor. The level of plant density on the mat (high or low) was inserted as a fixed variable, and the measured life history traits were used as response variables. All analyses were carried on R Environment ( $\mathrm{R}$ Core Team 2017), using the package lme4 (Bates et al. 2015).

\section{RESULTS}

All measured variables presented higher mean values in the high-density condition. Rosette height $(t=8.725$, $p<0.05$, Fig. 3a), diameter $(t=4.45, p<0.05$, Fig. 3b), and number of leaves $(t=4.71, p<0.05$, Fig. $3 c)$ were significantly higher on high-density conditions, allowing us to verify that plants were larger on high-density conditions.

The reproductive structures also showed the same pattern of response. The flower number was higher in high-density conditions; plants on low-density conditions did not present any flower, despite the presence of some scapes. The number of flower scapes $(t=-6.2208, p<$ .0001 , Fig. 4a) and the maximum length of flower scapes were both also higher on high-density conditions ( $t=6.63$, $\mathrm{p}<.05)$ (Fig. 4b).

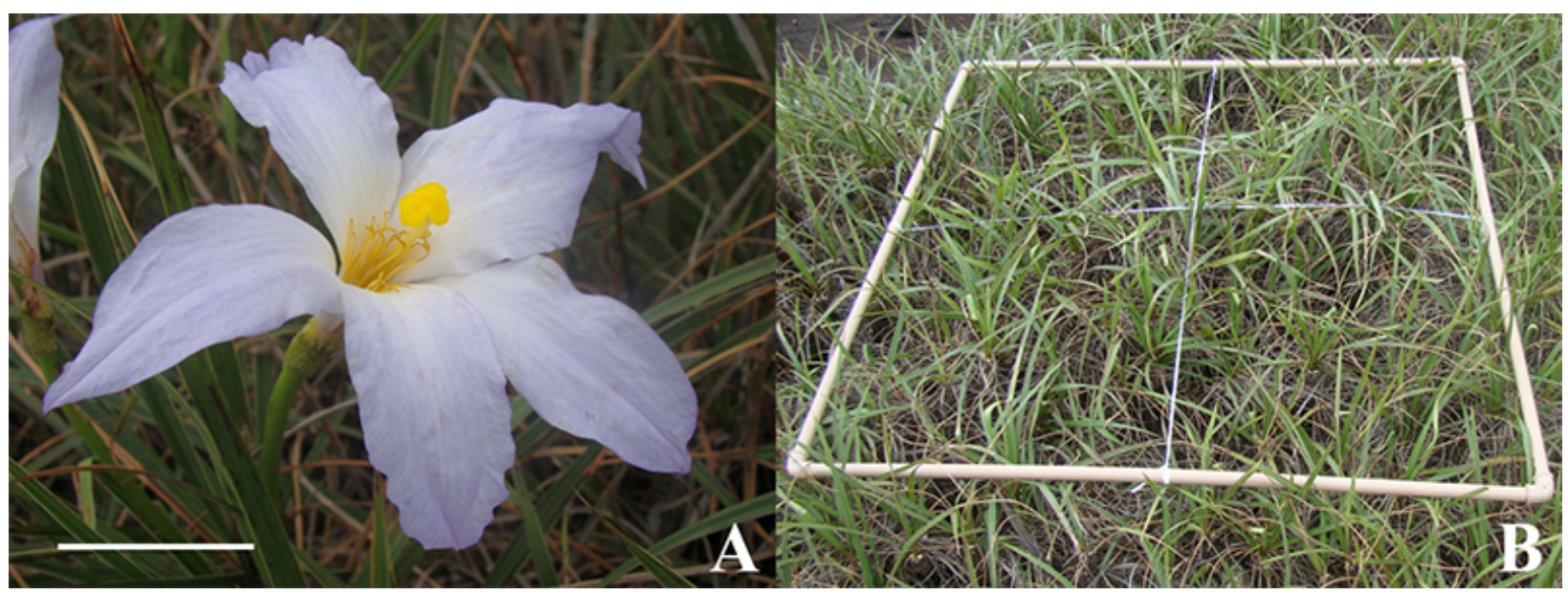

Figs. 2. A-B. A. A flowering specimen of Vellozia albiflora Pohl on gneiss outcrops of Morro do Cruzeiro, MG, Brazil. B. Sampling area showing a dense mat of plants, determined as the "high density" condition in this study. Bar $=3 \mathrm{~cm}$. 


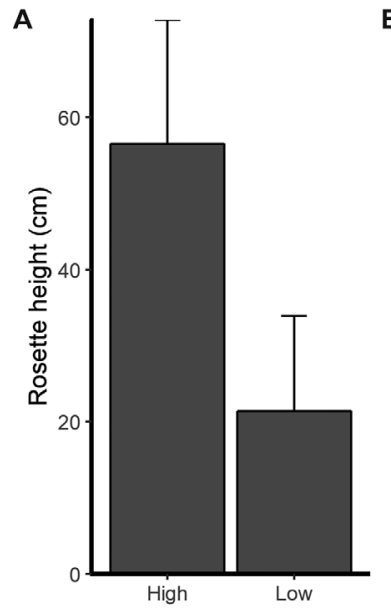

Plants density

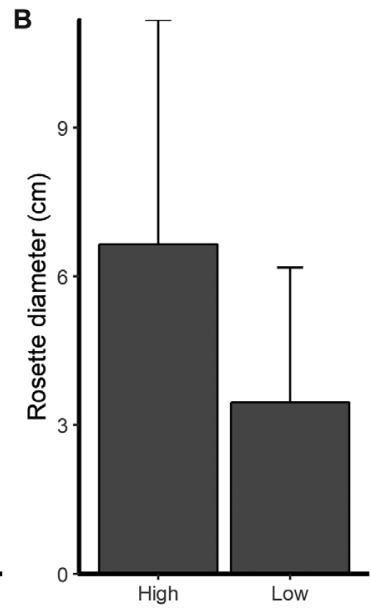

Plants density

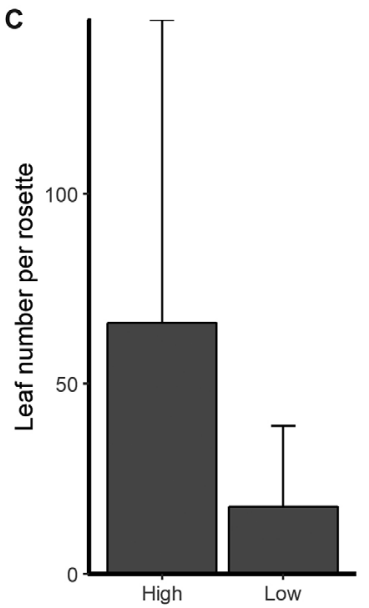

Plants density

Figs. 3 A-C. A. Rosettes height in centimeters in contrasting density conditions; B. Rosettes diameter in contrasting density conditions; C. Leaf number per rosette in contrasting density conditions. The bars represent the mean and the line is the standard deviation.
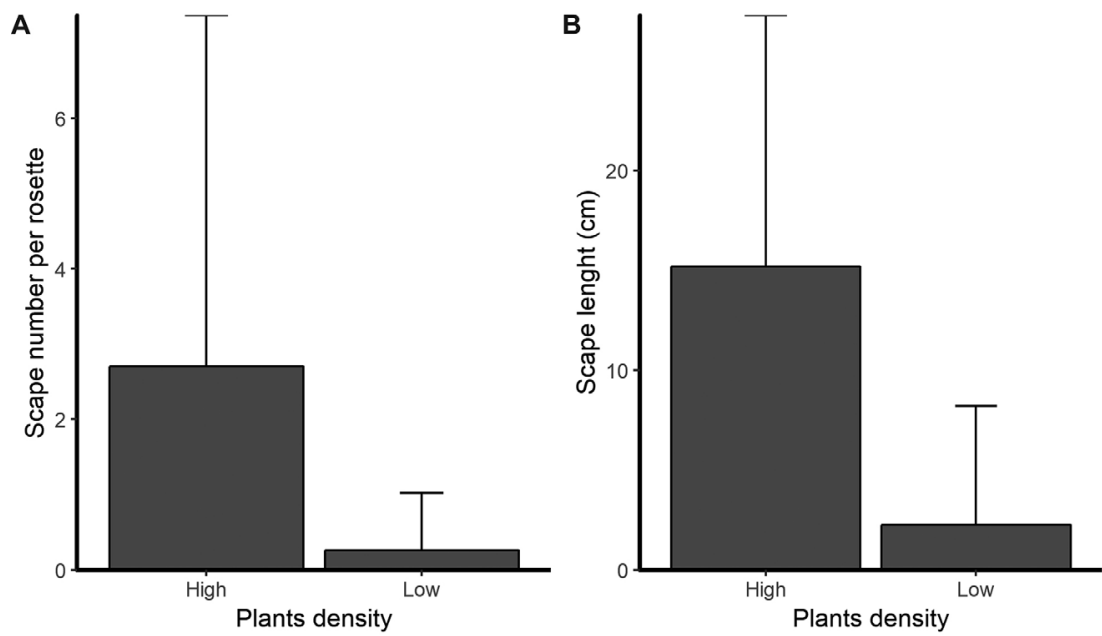

Figs. 4 A-B. A. Flower scape number per rosette in contrasting density conditions; B. Flower scape length in contrasting density conditions.

\section{DISCUSSION}

Regarding the influence of high density on vegetative morphological traits of $V$. albiflora, our results do not corroborate our hypothesis. The sampled rosettes presented larger sizes in high-density conditions, since both diameter and height presented higher values in densely crowded sampling units. Morphologic adaptations can arise in species under environmental pressures (Coelho et al. 2005; Alvarenga et al. 2013; Demetrio et al. 2014b). Since $V$. albiflora presents a rosette morphology (Mello-Silva 2009), greater diameters imply in more vigorous stalks. In shallow and sandy soils, common at rocky outcrops, a greater diameter would allow better fixation and sustention for the plants (Sposito \& Santos 2001), as it is common for other species that face uprooting (Demetrio et al. 2014b). In addition, in highly competitive habitats, plants may invest more biomass in traits that represent an advantage on resource acquisition (Alvarenga et al. 2013, Coelho et al., 2005), as $V$. albiflora showed by investing in larger plant sizes.

Another limiting factor in rocky outcrops is water availability (Madeira \& Fernandes 1999; Coelho et al. 2008). Vellozia is known for use their leaves as foraging organs to obtain water (Oliveira et al. 2005). The number of leaves was higher in plants in high-density conditions what imply in a greater ability of water uptake from the surrounding atmosphere. Besides, bigger plants in highdensity conditions probably experiment more favorable moisture conditions, since they form more closed "canopies", generating a crowded mat over the soil, and by concentrating more leaves per area they may increase the area of shaded habitats.

In relation to reproductive traits, our results clearly confirm high density as a trigger for sexual reproductive enhancement (Abrahamsom 1975), since in high-density 
conditions $V$. albiflora presented higher production of reproductive structures, here identified as the flower scapes that are directly involved in sexual reproduction, than in low-density conditions. Both number of flowers and number of scapes were higher in high-density conditions. In these conditions the formation of seeds can be considered as a persistence strategy, since seeds are persistence structures in other rocky outcrops as in campos rupestres (Garcia et al. 2007), due to the ability to remain in dormancy in the soil and germinate mainly under favorable condition, which is known for Vellozia species seeds (Garcia \& Diniz 2003, Garcia et al. 2007, Mota \& Garcia 2017). Even in resourcelimited stressing habitats the high production of seeds in crowded conditions seems to be the best evolutionary strategy for clonal plants (Ikegami et al. 2012). In fact, a bigger body size, as that presented by $V$. albiflora in highdensity conditions, may improve sexual reproduction, as noted for other plant species growing on rocky outcrops (Demetrio et al. 2014a).

Another strategy is the production of structures that can be dispersed and colonize other environments where resources are available or more abundant. Soils in rocky outcrops are usually shallow and poor (Negreiros et al. 2008), thus the existence of structures with persistence and dispersion functions in high densities are an optimal way of resource allocation for maximization of the fitness, granting higher possibilities of establishment and survival of new individuals.

Contrary to our hypothesis, the flower scapes length was higher in high-density conditions. At first, we thought that a higher energy limitation would decrease the investment in structures that are not directly linked to sexual reproduction. However, scapes have an important function on exposing flowers to pollinators. They can be considered as ancillary structures (Bazzaz et al. 1987), which are not directly involved on the processes that determine sexual reproduction but are imperative for the process functioning. This feature may represent a strategy to facilitate the dispersion to more favorable habitats with higher resource availability, what may represent an important evolutionary strategy in habitats where resources are distributed in patches, as rocky outcrops (Coelho et al. 2008, Negreiros et al. 2008) and show the importance of flower scapes in plant dispersion.

It is also possible that plants of $V$. albiflora allocated in densely crowded conditions presented higher number of flowers and greater flower scapes length because they also presented larger plant sizes. Body size is one of the most important factors regarding herbaceous perennial plant life-histories and several fitness components of these organisms are related to size (Méndez and Karlsson 2004), since it plays an important role on plants reproduction (Cheplick 2005, Demetrio et al. 2014).

Vellozia albiflora presented larger plant sizes and production of sexual structures in high-density conditions, what is counterintuitive in resource limited habitats as rocky outcrops. In this ecological framework we would expect that plants under low-density conditions would be more able to explore and acquire resources, and so present larger plant sizes and higher number of sexual reproduction structures. However, the enhancing of growth under resource limitation conditions may represent an alternative to improve competitive ability, and a higher number of sexual reproductive structures may represent a way to scape from crowded conditions via seeds production (Abrahamsom 1975), generating higher chances of individual persistence and reproductive success. It is probable that these features are linked to persistence and survival of individuals allocated in low resources habitats like rocky outcrops. It is also possible to consider that high density conditions were responsible for generating more suitable microhabitat conditions, with higher soil moisture,caused by the existence of shaded habitats composed by the V. albiflora big individuals, and higher soil organic matter contents, caused by the plant leaves decomposition. We suggest that future works should investigate ecophysiology and reproductive success to verify how density affects the performance of $V$. albiflora.

\section{ACKNOWLEDGEMENTS}

We thank CEMIG (Companhia Elétrica do Estado de Minas Gerais) for allowing the plants sampling in PETI area and the employees and manager of the ecological station, who provided information about sampled areas. We thank Victor Hugo Fonseca Oliveira for the constructive discussions. We also thank the anonymous reviewers for the contributions that helped to improve the first draft of the manuscript. This work was supported by UFLA (Universidade Federal de Lavras), and CAPES (Coordenação de Aperfeicoamento de Pessoal de Nível Superior), whose assistance we gratefully acknowledge.

\section{REFERENCES}

Abrahamsom, W.G. 1975. Reproductive strategies in dewberries. Ecology 3:721-726.

Alvarenga, E. A., Barbosa, M.E.A. \& Demetrio, G.R. 2013. Densitydependent morphological plasticity and trade-offs among vegetative traits in Eichhornia crassipes (Pontederiaceae). Acta Amazonica 43(4):455-460.

Alves, R.J.V. \& Kolbek, J. 1994. Plant species endemism in savanna vegetation on table mountains (Campo Rupestre) in Brazil. Vegetatio 113: $125-139$

Bates, D., Maechler, M., Bolker, B., Walker, S. 2015. Fitting Linear MixedEffects Models Using lme4. Journal of Statistical Software, 67: 1-48.

Bazzaz, F.A., Chiariello, N.R., Coley, P.D., \& Pitelka, L.F. 1987. Allocating resources to reproduction and defense. BioScience 37:58-67.

Benites, V.M., Schaeffer, C.E.G.R., Simas, F.N.B. \& Santos, H.G. 2007. Soils associated with rock outcrops in the Brazilian mountain ranges Mantiqueira and Espinhaço. Revista Brasileira de Botânica 30:569577.

Borba, E.L. \& Braga, P.I.S. 2003. Biologia reprodutiva de Pseudolaelia corcovadensis (Orchidaceae): melitofilia e autocompatibilidade em uma Laeliinae basal. Revista Brasileira de Botânica 26:541-549.

Cheplick, G. P. 2005. The allometry of reproductive allocation. In Reproductive allocation in plants (E. Reekie, \& F. Bazzaz, eds). Elsevier-Academic Press, San Diego, California, USA, p, 97- 128. 
Coelho, F.F., Capelo, C., Ribeiro, L.C. \& Figueira, J.E.C. 2008. Reproductive modes in Leiothrix (Eriocaulaceae) in south-eastern Brazil: the role of microenvironmental heterogeneity. Annals of Botany 101: 353-360.

Coelho, F.F., Deboni, L. \& Lopes, F.S. 2005. Density-dependent reproductive and vegetative allocation in the aquatic plant Pistia stratiotes (Araceae). Revista de Biologia Tropical 53: 369-376.

Coelho, F.F., Martins, R.P., Figueira, J.E.C., Demetrio, G.R. 2014. Soil factors effects on life history attributes of Leiothrix spiralis and Leiothrix vivipara (Eriocaulaceae) on rupestrian grasslands in Southeastern Brazil. Brazilian Journal of Biology 74(4):828-836.

Conceição, A.A. \& Giulietti, A.M. 2002. Composição florística e aspectos estruturais de campo rupestre em dois platôs do Morro do Pai Inácio, Chapada Diamantina, Bahia, Brasil. Hoehnea 29:37-48.

Demetrio, G.R., Barbosa, M.E.A. \& Coelho, F.F. 2014a. Water leveldependent morphological plasticity in Sagittaria montevidensis Cham. and Schl. (Alismataceae). Brazilian Journal of Biology, 74(3 Suppl 1):S199-206.

2014b. Body size and clonality consequences for sexual reproduction in a perennial herb of Brazilian rupestrian grasslands. Brazilian Journal of Biology 74(3):744-749.

Garcia, Q.S., Diniz, I.S.S. 2003. Comportamento germinativo de três espécies de Vellozia da Serra do Cipó, MG. Acta Botanica Brasilica 17(4):487-494.

Garcia, Q.S., Jacobi, C.M., Ribeiro, B.A. 2007. Resposta germinativa de duas espécies de Vellozia (Velloziaceae) dos campos rupestres de Minas Gerais, Brasil. Acta Botanica Brasilica 21(2):451-456.

Giulietti, A.M. \& Pirani, J.R. 1988. Patterns of geographic distribution of some plant species from Espinhaço Range, Minas Gerais and Bahia, Brazil. Pp. 39-69. In Proceedings of a Workshop on Neotropical Distribution Patterns (P.E. Vanzolini \& W.R. Heyer, eds.). Rio de Janeiro, Academia Brasileira de Ciências.

Harper, J. L. 1977. Population biology of plants. London, Academic Press, 892p.

Ikegami, M., Whigham, D.F. \& Werger, M.J.A. 2008. Optimal biomass allocation in heterogeneous environments in a clonal plant - spatial division of labor. Ecological Modelling 213(2): 156-164.

2012. Effects of local density of clonal plants on their sexual and vegetative propagation strategies in a lattice structure model. Ecologial Modelling 234:51-59.

Komac, B. \& Alados, C.L. 2012. Fluctuating asymmetry and Echinospartum horridum fitness components. Ecological Indicators 18: 252-258.

Landau, E.C., Gonçalves-Alvim, S.J., Fagundes, M. \& Fernandes, G.W. 1998. Riqueza e abundância de herbívoros em flores de Vellozia nivea (Velloziaceae). Acta Botanica Brasilica 12: 403-409.

Madeira, J.A. \& Fernandes, G.W. 1999. Reproductive phenology of sympatric Chamaecrista taxa of Chamaecrista (Leguminosae) in Serra do Cipó, Brazil. Journal of Tropical Ecology 15: 463-479.

Medina, B.M.O., Ribeiro, K.T. \& Scarano, F.R. 2006. Plant-plant and plant-topography interactions in a rock outcrop at high altitude in southeastern Brazil. Biotropica 38:27-34

Meireles, S.T., Matos, E.A. \& Silva, A.C. 1997. Potential desiccation tolerant vascular plants from southeastern Brazil. Polish Journal of Environmental Studies 6:17-21.
Mello-Silva, R. 2009. Flora de Grão-Mogol, Minas Gerais: Velloziaceae. Boletim de Botânica da Universidade São Paulo 27(1): 109-118.

Méndez, M., Karlsson, P.S. 2004. Between-population variation in sizedependent reproduction and reproductive allocation in Pinguicula vulgaris (Lentibulariaceae) and its environmental correlates. Oikos 104(1):59-70.

Mota, L.A.S., Garcia, Q.S. 2017. Germination patterns and ecological characteristics of Vellozia seeds from high-altitude sites in southeastern Brazil. Seed Science Research 23 67-74;

Negreiros, D., Moraes, M.L.B, Fernandes, G. W. 2008 Caracterização da fertilidade dos solos de quatro leguminosas de campos rupestres, Serra do Cipó, MG, Brasil. Journal of Soil Science Plant Nutrition 8(4):30-39.

Oliveira, R.S., Dawson, T.E. \& Burgess, S.S. 2005. Evidence for direct water absortion by the shoot of the dessication-tolerant plant Vellozia flavicans in the savannas of central Brazil. Journal of Tropical Ecology 21:585-588.

Plaza, E.H., Navarrete, L., Lacasta, C. \& Gonzáles-Andujar, J. L. 2012. Fluctuations in plant populations: role of exogenous and endogenous factors. Journal of Vegetation Science 23:640-643

Pedralli, G. \& Teixeira, M.C.B. 1997. Levantamento florístico e principais fisionomias na Estação de Pesquisa e Desenvolvimento Ambiental de Peti, Santa Bárbara, MG, Brasil. Iheringia, Série Botânica 48: 15-40.

Porembski, S. 2007. Tropical inselbergs: habitat types, adaptive strategies and diversity patterns. Revista Brasileira de Botânica 30:579-586.

Porembski, S., Martinelli, G., Ohlemüller, R. \& Barthlott, W. 1998. Diversity and ecology of saxicolous vegetation mats on inselbergs in the Brazilian Atlantic rainforest. Diverity and Distribution, 4:107-119.

R Core Team (2017). R: A language and environment for statistical computing. R Foundation for Statistical Computing, Vienna, Austria. URL https://www.R-project.org/.

Rapini, A., Ribeiro, P.L., Lambert, S. \& Pirani, J.R. 2008. A flora dos campos rupestres da Cadeia do Espinhaço. Megadiversidade 4:16-24.

Ribeiro, K.T. \& Fernandes, G.W. 2000. Patterns of abundance of a narrow endemic species in a tropical and infertile montane habitat. Plant Ecology 147:205-218.

Scarano, F.R., Duarte, H.M., Ribeiro, K.T., Rodrigues, P.J.F.P., Barcellos, E.M.B., Franco, A., Brulfelrt, J., Deleéns, E. \& Lüttge, U. 2001. Four sites of contrasting environmental stress in southeastern Brazil: relations of species, life form diversity, and geographic distribution to ecophysiological parameters. Botanical Journal of the Linnean Society 136:345-364.

Sposito, T.C. \& Santos, F.A.M. 2001. Scaling of stem and crown in eight Cecropia (Cecropiaceae) species of Brazil. American Journal of Botany, 88:939-949.

Stearns, S.C. 1992. The evolution of life histories. Oxford, Oxford University Press, 262p.

Sultan, S.E. 2000. Phenotypic plasticity for plant development, function and life-history. Trends in Plant Science 5: 537-542.

.2003. Phenotypic plasticity in plants: a case study in ecological development. Evolution \& Development 5: 25-33.

Weiner, J., 2004. Allocation, plasticity and allometry in plants. Perspectives in Plant Ecology, Evolution and Systematics, 6, 207-215. 